\title{
A PROPOSED 'LADDER OF LEARNING' FOR ACADEMICS' PROFESSIONAL DEVELOPMENT IN TEACHING
}

\section{A. Cameron*}

Science Teaching and Learning Centre, Faculty of Science

e-mail: Ann.Cameron@wits.ac.za

\section{Woods*}

Centre for Learning, Teaching and Development

e-mail: Christine.Woods@wits.ac.za

*University of the Witwatersrand

Johannesburg, South Africa

\section{ABSTRACT}

In higher education institutions globally, academic development practitioners whose work is to professionally develop academic staff in the area of teaching, have historically come into the profession without specific formal training. Their ideas and practice stem from the context of their work and life experience, and their knowledge grows with experience on the job. As a result, there is a great variety of knowledge and expertise that shapes professional development activities in higher education institutions. The aim of this article is to report on the findings of an investigation which drew on the collective wisdom of academic development practitioners who participated in a workshop on the topic of professional development. Activity Theory was used as an interpretive lens to identify key aspects from the data and align these onto a 'Ladder of Learning' - a hierarchically structured framework to inform appropriate professional development activities for academics. The insights gained from the findings may be used to strengthen academic professional development practice in support of ongoing improvement of the quality of teaching.

Keywords: Professional development; higher education; teaching and learning; Activity Theory; Ladder of Learning.

\section{INTRODUCTION}

Higher education globally has undergone profound changes in the past few decades. Globalisation and internationalisation have created greater demand for and access to higher education, resulting in large classes with demographically diverse student cohorts. Information and Communication Technology (ICT) and the rise of social media have also added to rapidly evolving higher education contexts and the need for innovative pedagogies to support learning and teaching. Despite these changes and the urgent need to address poor student throughput rates, higher education institutions in South Africa, unlike growing international trends, do not 
require academics to undergo formal pre- or in-service training to promote appropriate, responsive learning and teaching (L\&T) practice. The economic reality that government subsidies in South Africa are linked to student throughput rates has, however, provoked the need for higher education institutions to provide professional development programmes to develop academics as teachers (CHE 2013, 153). This is in line with findings of a review in the United Kingdom in 2010 on higher education that suggested that university funding should be linked to the professional development of academics (Gibbs 2014, 1).

This United Kingdom review also highlighted the pressures that have been brought to bear on academics whose roles encompass teaching, research, and academic citizenship or service. These areas are not always equally regarded in terms of career progression. There is especially a tension in many higher education institutions between teaching and research, with research often attracting more funding and having more status than teaching. In order to achieve an equitable balance between teaching and research, it has become increasingly apparent that academics' teaching competence needs to be developed and rigorously evaluated. The challenge is to distil the complex range of attitudes, attributes, knowledge and practices that constitute quality teaching into a tool that is meaningful for both development and accountability.

Within the specific and unique contextual needs of higher education institutions around the world, common challenges have resulted in a range of responses that focus on teaching, to support and professionally develop academic staff. Academic development practitioners who work in higher education institutions to promote the professional development of academic staff, have historically migrated into the profession (Green and Little, in Linder and Felten 2015 , 1) without specific formal training (Gosling 2009, 8). There is as yet no international consensus on the domain of knowledge or theories that define their discourse and practice, with the result that academic development practitioners' ideas and practices stem from their previous work contexts and life experience, and their knowledge and practice grow specifically with experience on the job. Programmes and activities geared towards academics' professional development of teaching are grounded in local needs and contexts, although there is recognition at a broader level of common purposes and common challenges. It is inevitable that such (unregularised) responses to common needs and common challenges will eventually, through sharing experiences, lead to shared practice.

Recent collaborative research in Australian universities (Australian University Teaching Criteria and Standards Project) (AUTCSP 2014) offers a useful framework to define national teaching criteria and standards. Its seven criteria are described and conceptualised as a matrix 
to give examples of performance at each of five levels of career progression. In Sweden, Lund University has identified three overarching principles of 'good' teaching, described as 'pedagogical competence', which they have used to recognise and reward excellent teaching practice. Lund University’s conception of a ‘Pedagogical Academy’ (Olsson, Mårtensson and Roxå 2010) is a structure that is used to evaluate pedagogical competence. These 'good teaching' principles have been used to conceptualise standards that enable academic development practitioners to support academics in growing their expertise. The standards enable academics to be purposeful and focused in developing their expertise, and provide evaluators with the tools to assess the levels of pedagogical competence of individual academic staff members.

Both the Swedish and Australian frameworks use teaching portfolios as a means of assessing teaching expertise. At Lund University, judging a portfolio as successful rewards the academic with the title of 'Excellent Teaching Practitioner' which is accompanied by monetary rewards for the individual and his/her respective school. In Australia, the portfolio is presented as evidence of teaching competence, and financial reward is linked to promotion and career progression, with increased expectations as higher levels of competence are achieved. Both the Australian and Swedish frameworks are sophisticated models that represent deep engagement with the challenges associated with articulating what is meant by 'good' or 'quality' teaching. These models demonstrate teaching as being of equal importance to research for promotion and career progression in an institution. In both cases, institutional and national higher education structures and policies have been used by academic developers to support, develop, and recognise academics’ teaching expertise.

In institutions of higher education, Gibbs $(2014,2)$ notes clear stages which teachers go through as they gain teaching experience, and says that early career academics and distinguished teachers are likely to benefit from different forms of professional development support. He points out that early career academics or emerging teachers (typically graduate students and teaching assistants) are concerned, for example, with whether students like them or are impressed by them, and consequently may benefit from courses that create an awareness of students' needs and how these needs may be met through a student-centred approach to learning and teaching. Those teachers whose expertise is developing are more concerned with the transmission of knowledge and students' mastery of subject matter. Some developing teachers may begin to focus on how effective they are and reflect on what they can do to improve student learning, while others may go on to research their teaching and contribute to the scholarship of teaching and learning. These developing teachers may benefit from courses 
that further develop their practice. Peer reviews that build their confidence, or challenge them to reflect more deeply, may also be beneficial. While some teachers never move beyond a focus on content (Gibbs 2014, 2), others make the transition to practices that are born out of deeply reflective and reflexive engagement with student learning. Such distinguished teachers often contribute to teaching excellence through mentoring early- and mid-career academics and may engage in research and scholarship that serves to grow the field in higher education.

In South Africa, the size and shape of higher education institutions has changed dramatically over the past twenty years. The teaching pressures on academics associated with these changes relate mainly to large classes and meeting the needs of diverse and underprepared student cohorts, as well as growing managerialism and administration arising from attempts to regulate teaching through quality assurance mechanisms. Academics in higher education institutions now increasingly deal with under-prepared students (owing to widening access and a failing schooling system) and pressure to maintain and/or increase student throughput rates. In this environment, academics also face a 'publish or perish' culture and the implementation of performance management. Centres for Learning and Teaching have been established in most higher education institutions to support academics and students in dealing with the challenges they face. Most Centres employ academic development practitioners to support the professional development of academics and to further develop institutional excellence in teaching. However, these Centres have tended to develop as silos of expertise, where academic development practitioners respond to local needs, without reference to a national expression of standards for quality teaching.

This article reports on an investigation to consider the range of professional development practices in South Africa, drawing on data collected at a 2014 Higher Education Learning and Teaching Association of Southern Africa (HELTASA) Professional Development Special Interest Group Workshop, ${ }^{1}$ hereafter referred to as 'the workshop'. The purpose of the workshop was to develop a shared understanding of what constitutes professional development practice, as aligned with the career progression and support of academics, from emergent, through developing, to distinguished teaching practice. The purpose of this article is to report on the outcomes of the workshop and propose a framework, focusing on teaching, for the professional development of academics in higher education institutions in South Africa. Activity Theory was used as a conceptual framework to enable the emergence of aspects of professional development practices which were aligned to career progression, creating what the authors refer to as a 'Ladder of Learning'. 


\section{CONCEPTUAL FRAMEWORK}

Engeström's version of Activity Theory was used to analyse the workshop data and establish which professional development activities are considered appropriate for academics, as they progress in their careers from emerging to developing to distinguished practice. Activity Theory was an appropriate conceptual framework for this investigation, since it assumes that human action takes place within specific social and historical contexts, and that these contexts cannot be separated from action. Engeström argues that contexts (such as teaching in higher education) are Activity Systems, and that 'an activity system integrates the subject, the object, and the instruments (material tools as well as signs and symbols) into a unified whole' $(1993,67)$.

For Engeström, an Activity System comprises a set of inter-connected triangles with mediating 'elements' which include:

- 'subjects' - participants in the activity system;

- ' 'objects' - the goal towards which the activity is directed

- 'tools' - both conceptual and material, which are used in the activity system to mediate experience;

- 'rules' - the norms and conventions which regulate, constrain and facilitate action;

- 'community' - those who share the goal of the activity system but are not the primary subjects in the activity, and

- 'division of labour' - the division of tasks and power.

The relationship between the elements in an Activity System is illustrated in Figure 1.

The elements of an Activity System are not discrete entities existing in separation from each other. They are dynamic and continuously interact with each other. The elements define the Activity System as a whole, with each element contributing to the analysis, in this case, of the unique context of different higher education institutions in terms of the professional development of academics in the area of teaching.

The dynamic interplay between the elements of the Activity System is similar to the interplay between structure, culture and agency (Archer 1995; 1996; 1998). Participants may use conceptual and material 'tools' to mediate their capacity and agency to act within the Activity System. The 'rules' and 'division of labour' elements may contribute to structures that enable or constrain the agency of participants in the Activity System, while the 'community' element may contribute to the culture in the Activity System. Thus the top half of the Activity System represents the participants' agency, whereas the bottom half represents structure and 
culture.

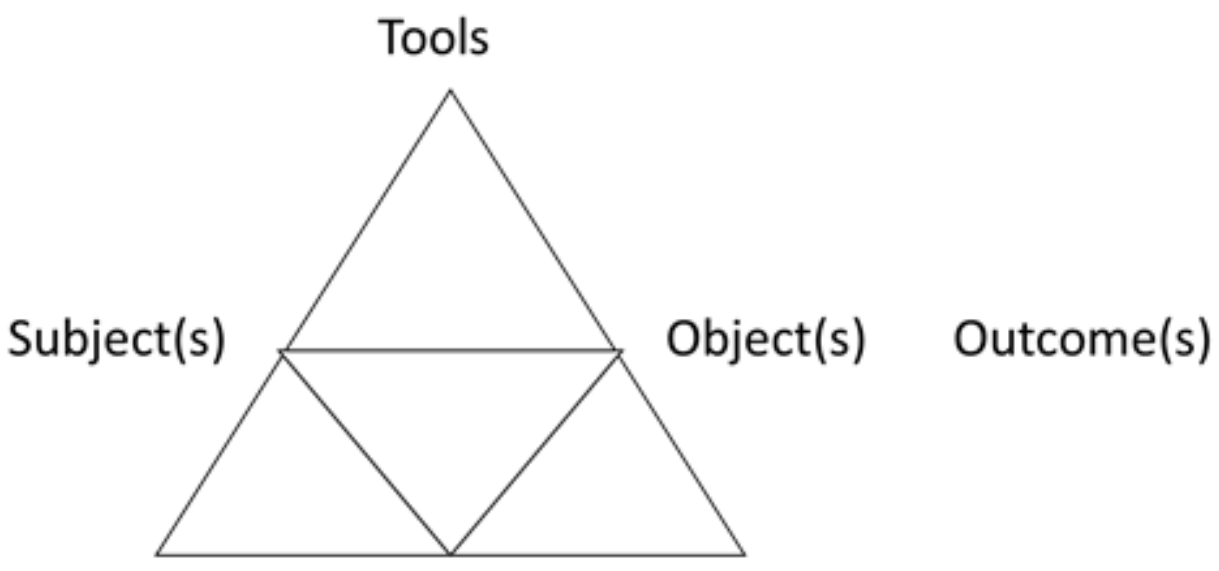

\section{Rules Community Division of labour}

Figure 1: Engeström's Activity System $(1987,78)$

At this point, an example aligning social realist conceptions of structure, culture and agency with the elements in an Activity System that focuses on the professional development of academics in higher education, may be useful. The goal or object of such an Activity System drives the activity, according to Engeström, and academics (subjects) may use their agency to engage in professional development activities to further develop their teaching practice (object) in order to improve student success or throughput rates (outcome). This would require academics to use disciplinary knowledge and theories of learning and teaching (conceptual tools) as well as library facilities and computers (material tools) to reflect on and further develop their teaching. The academics' involvement in professional development activities may be either constrained or enabled by institutional structures and practices; for example, promotion practices with specific requirements for different career levels (rules). Academics may be required to balance their workloads, comprising teaching, research and academic citizenship (division of labour), while navigating their career progression. The community, in Activity Theory, may consist of other academic colleagues and/or administrators who directly or indirectly affect the institutional culture and influence whether or not academics are able to develop their teaching to improve student success or throughput rates.

An Activity System is, by its nature, in a process of constant change because different elements may exist in tension or contradiction with one another. The notion of contradiction is central to the understanding of change in an Activity System, as there are constant contradictions within and between its elements, as well as between associated Activity Systems. 
These contradictions provide the impetus for change and development. When an Activity System is 'disturbed', or contradictions occur, the focus needs to be on the contradictions and their origins in systemic causes, since, as Engeström (2000, 305) points out, resolution may only come about when the system is changed.

Not all contradictions will be resolved, however, and in these instances concrete innovative actions may lead to a 'cycle of expansive learning which may lead to a redefinition of the object of the activity’ (Engeström 2000, 308-309). For example, academics may want to participate in professional development activities to develop their teaching practice (object) in order to enhance student success (outcome). However, sufficient time (material tool) to participate in such activities may not be allocated in their workloads (division of labour), resulting in academics either not participating, or participating sporadically, in professional development activities. This, in turn, may negatively affect their ability to develop their teaching practice (object) and improve student success (outcome). Similarly, if compliance with ad hominem criteria for promotion (object) drives the activity, then it cannot be assumed that the desired outcome of improved student learning will be achieved. In both examples, tensions or contradictions point to challenges at a systemic level since academics may want to engage in professional development activities, but implementation of institutional policies, such as ad hominem promotion criteria and workload allocations (systemic causes) may impact on the intention and time devoted to such activities. If these contradictions are to be resolved, institutional policies and the implementation thereof need to change to enable academics to engage in professional development activities to further develop their teaching, and to improve throughput rates as a result.

\section{GATHERING THE WORKSHOP DATA}

The workshop was held at the University of the Witwatersrand on 15 and 16 August 2014, and was attended by 63 participants from 13 higher education institutions and one representative from the Council on Higher Education. The aim of the workshop was to draw on the academic development practitioners' knowledge and expertise to ascertain which interventions and practices they considered successful for each level on the Ladder of Learning. Workshop participants gave their consent for the data to be analysed, and the analysis was subsequently presented at the HELTASA Conference held at the University of the Free State in November 2014.

At the start of the workshop the presenters shared a graphic representation of the Ladder of Learning with participants (Table 1 below). 
Table 1: Representation of career path levels on the Ladder of Learning

\begin{tabular}{|l|l|}
\hline Ladder of Learning & Career Path Levels \\
\hline Distinguished & Associate Professor and Professor \\
\hline Developing & Lecturer and Senior Lecturer \\
\hline Emerging & Associate Lecturer and Postdocs \\
\hline
\end{tabular}

The Ladder represents three steps that loosely align with academics' career progression, i.e. from early career academics (associate lecturers and post-doctoral students), to developing or mid-career academics (lecturers and senior lecturers) and academics at an advanced level (associate professors and professor). The first step on the Ladder of Learning thus focuses on early career academics whose teaching expertise may be classified as emerging. The next step focuses on academics whose teaching expertise is developing, and the final step represents academics whose teaching expertise is advanced and whose practice may be considered distinguished.

Having been organised into groups of six, workshop participants were asked to complete three tasks:

- $\quad$ Task 1: To write down the interventions/practices they had implemented that had been most successful in developing expertise in teaching.

- $\quad$ Task 2: To share their interventions/practices with each other and then to reach consensus on three key interventions/practices deemed to be most effective in developing academics' knowledge and expertise in teaching. The purpose of this step was to serve as a first level of filtering in identifying commonly successful interventions/practice.

- $\quad$ Task 3: To agree as a group on a position on the Ladder of Learning where these three key interventions/practices would be most appropriate in developing academics' knowledge and expertise in teaching.

The aspects that participants attributed to key interventions and practices that most effectively developed academics' teaching knowledge and expertise were coded using the elements in Activity Theory. An iterative process was used where words, phrases and/or sentences that were associated with each element were highlighted, out of which categories and themes were constructed and refined. The themes that emerged essentially identified the key aspects that made up those professional development activities that were identified as most successful by 
the workshop participants. Activity Theory thus acted as a conceptual framework to identify the aspects that served to populate the Ladder of Learning. These aspects were then further developed on the Ladder by drawing on literature and other teaching frameworks to provide a basis for discussing the findings.

\section{FINDINGS AND DISCUSSION}

The subjects in this Activity System were academics whose participation in professional development activities was directed at developing their knowledge and expertise in teaching with a view to improving their student throughput rates. Academics do not necessarily share a common understanding of what 'professional development' means, which may affect their agency and how they engage in such activities. Academics also come from diverse disciplinary backgrounds and mainly draw on their past experiences to develop their teaching. The progressive professional development opportunities aligned on the Ladder of Learning may therefore afford academics the opportunity to clarify what is meant by 'professional development' of teaching, and may offer insights into the kinds of development opportunities they may benefit from as regards career progression.

Both conceptual and material tools mediated the experiences of the academics, in order to achieve the outcome of the activity. This mediation is an active process in which the use of the tools is not the only means of achieving the goal: tools may be created and transformed in the process, and may influence the agency, nature and experiences of the academics. Merely having a tool available is not enough to ensure that it mediates and directs the academics' actions. The tool needs to be incorporated into the activity for it to become effective.

The key aspects identified by workshop participants that were coded as conceptual tools were: the process of reflection; application of educational theory to practice; developing teaching portfolios; and engaging in the scholarship of learning and teaching. Products such as portfolios, published journal articles and teaching awards were coded as material tools. Although there are other material tools that may mediate the academics' professional development, such as access to computers, journals, library books and educational technologies, these were not specifically mentioned by workshop participants, and therefore were not included in the analysis.

Drawing on the workshop data, institutional practices and literature (Gibbs 2014; AUTCSP 2014; Olsson et al. 2010) the progressive development of these conceptual and material tools on the Ladder of Learning is shown in Table 2.

Table 2: Progressive development of conceptual and material tools on the Ladder of Learning 


\begin{tabular}{|c|c|c|c|}
\hline \multirow[b]{2}{*}{ Aspects } & \multicolumn{3}{|l|}{ Ladder of Learning } \\
\hline & $\begin{array}{l}\text { Emerging } \\
\text { (Postdoc and Associate } \\
\text { Lecturer) }\end{array}$ & $\begin{array}{l}\text { Developing } \\
\text { (Lecturer and } \\
\text { Senior lecturer) }\end{array}$ & $\begin{array}{l}\text { Distinguished } \\
\text { (Associate Professor } \\
\text { and Full Professor) }\end{array}$ \\
\hline Reflection & $\begin{array}{l}\text { An inward focus on self, } \\
\text { related to teaching (How am I } \\
\text { doing? Do I look as if I know } \\
\text { what I am talking about? Do } \\
\text { students like me?) } \\
\text { Participation in activities that } \\
\text { serve to create awareness } \\
\text { Induction / probation } \\
\text { programmes / workshops / } \\
\text { L\&T toolkits }\end{array}$ & $\begin{array}{l}\text { A shifting focus from content and } \\
\text { transmission teaching to focus on } \\
\text { student learning (Why are } \\
\text { students not learning? How and } \\
\text { what do students learn? How can } \\
\text { I shift my practice to assist } \\
\text { learning?) Possibly fast tracking } \\
\text { through attendance at PGDipHE } \\
\text { and/or courses/workshops on L\&T }\end{array}$ & $\begin{array}{l}\text { An outward focus i.e. on } \\
\text { others (deepening } \\
\text { engagements with } \\
\text { students and with less } \\
\text { experienced academics) } \\
\text { playing the role of } \\
\text { mentor / facilitator / } \\
\text { coach / co-creator of } \\
\text { knowledge) }\end{array}$ \\
\hline Theory & $\begin{array}{l}\text { Ignorance of theory (Teaching } \\
\text { as they were taught; intuitive or } \\
\text { common-sense approach to } \\
\text { teaching) }\end{array}$ & $\begin{array}{l}\text { Growing exposure to and } \\
\text { awareness of theoretical } \\
\text { underpinnings of L\&T (Growing } \\
\text { understanding of own practice } \\
\text { and experience in relation to } \\
\text { theory) }\end{array}$ & $\begin{array}{l}\text { Knowledge of theory and } \\
\text { interest in application to } \\
\text { own and others' } \\
\text { contexts; leadership in } \\
\text { introducing / inducting } \\
\text { others to pedagogy as a } \\
\text { discipline }\end{array}$ \\
\hline Portfolios & $\begin{array}{l}\text { Focus on workload (How much } \\
\text { I do? How many students do I } \\
\text { teach? How many hours for } \\
\text { lectures, labs, tutorials and } \\
\text { marking?) }\end{array}$ & $\begin{array}{l}\text { Growing reflection on how } \\
\text { students are learning (How have I } \\
\text { understood and responded to } \\
\text { students' learning needs?) }\end{array}$ & $\begin{array}{l}\text { Reflection on } \\
\text { contributions from and to } \\
\text { theory, reflection on } \\
\text { deepening student } \\
\text { learning, and inspiring } \\
\text { students to postgraduate } \\
\text { study }\end{array}$ \\
\hline $\begin{array}{l}\text { Scholarship of } \\
\text { Teaching and } \\
\text { Learning }\end{array}$ & $\begin{array}{l}\text { Ignorance of / lack of interest } \\
\text { in education journals. Focus is } \\
\text { on own disciplinary area. }\end{array}$ & $\begin{array}{l}\text { Growing awareness of and } \\
\text { reference to scholarly articles on } \\
\text { pedagogic practice, possibly } \\
\text { limited to education in own } \\
\text { disciplinary area. Attend / present } \\
\text { at School or Faculty L\&T } \\
\text { symposiums or involvement in } \\
\text { education- related committees, } \\
\text { either in institution or nationally }\end{array}$ & $\begin{array}{l}\text { Contributes to education } \\
\text { journals or journals on } \\
\text { education. National / } \\
\text { international participation } \\
\text { in / leadership of } \\
\text { committees / } \\
\text { conferences on } \\
\text { education. }\end{array}$ \\
\hline $\begin{array}{l}\text { Recognition of } \\
\text { teaching } \\
\text { expertise } \\
\text { (Awards) }\end{array}$ & $\begin{array}{l}\text { Lack of awareness of awards; } \\
\text { insufficient quality of } \\
\text { experience and skills needed } \\
\text { to be eligible for teaching } \\
\text { awards }\end{array}$ & $\begin{array}{l}\text { Growing awareness of school / } \\
\text { faculty / institutional awards; } \\
\text { sufficiently developed expertise, } \\
\text { but lack of participation may be } \\
\text { due to pressures and time } \\
\text { constraints related to balancing } \\
\text { research and teaching demands }\end{array}$ & $\begin{array}{l}\text { National / International } \\
\text { awards or invitations to } \\
\text { be keynote speaker at } \\
\text { education conferences }\end{array}$ \\
\hline
\end{tabular}

The rule element in this Activity System concerns the explicit and implicit regulations, norms and conventions that constrain or enable academics' actions and agency within the Activity System. Workshop participants pointed out that institutional structures such as probation and promotion play a key role in guiding the professional development of academics. These practices may be viewed in the Activity System as rules that affect academics' career progression which loosely align with the Ladder of Learning. For example, induction practices mediate the academics' professional development experience, particularly for early career academics in the emerging stage on the Ladder. Probation and promotion criteria focused on teaching are not always articulated and/or implemented in the same way in and across 
institutions, nationally and internationally. This may be because there is no consensus on 'quality' teaching or a conceptually-based definition of it (AUTCSP 2014). However, it is important to develop a shared understanding of quality teaching specifically in a South African context, to inform national standards pertaining to teaching in higher education. Such a set of national standards could define what counts as evidence of quality teaching. The Ladder of Learning could provide a 'home grown' framework for the accreditation of university teachers once further inputs and feedback have been solicited and the Ladder further developed, as envisaged in the next phase of the research. Quality assurance of teaching is essential for enhancing student learning, for accountability and reporting purposes, and to guide the further development of learning and teaching.

The progressive development of the rules on the Ladder of Learning is shown in Table 3, which draws on the workshop data, institutional practices and literature (Gibbs 2014; AUTCSP 2014; Olsson et al. 2010).

Table 3: Progressive development of rules on the Ladder of Learning

\begin{tabular}{|c|c|c|c|}
\hline \multirow[b]{2}{*}{ Aspects } & \multicolumn{3}{|l|}{ Ladder of Learning } \\
\hline & $\begin{array}{l}\text { Emerging } \\
\text { (Postdoc and Associate } \\
\text { Lecturer) }\end{array}$ & $\begin{array}{l}\text { Developing } \\
\text { (Lecturer and } \\
\text { Senior lecturer) }\end{array}$ & $\begin{array}{l}\text { Distinguished } \\
\text { Associate Professor } \\
\text { and Full Professor }\end{array}$ \\
\hline $\begin{array}{l}\text { Induction } \\
\text { Practices }\end{array}$ & $\begin{array}{l}\text { Institution- and/or Faculty- } \\
\text { based programmes that } \\
\text { introduce new staff to peers } \\
\text { and senior colleagues and } \\
\text { create an awareness of } \\
\text { institutional/faculty policies } \\
\text { and practices and work } \\
\text { expectations }\end{array}$ & $\begin{array}{l}\text { Institution- and/or Faculty- } \\
\text { based programmes that } \\
\text { introduce staff new to the } \\
\text { system to peers and senior } \\
\text { colleagues and create an } \\
\text { awareness of } \\
\text { institutional/faculty policies and } \\
\text { practices and work } \\
\text { expectations }\end{array}$ & $\begin{array}{l}\text { Makes presentations at, and } \\
\text { encourages new staff to } \\
\text { attend Induction programmes; } \\
\text { acts as a mentor for new staff }\end{array}$ \\
\hline $\begin{array}{l}\text { Probation } \\
\text { Practices }\end{array}$ & $\begin{array}{l}\text { Short-term contract } \\
\text { positions with no probation } \\
\text { requirements }\end{array}$ & $\begin{array}{l}\text { Minimum teaching } \\
\text { competencies evident to } \\
\text { confirm appointment } \\
\text { at developing level }\end{array}$ & $\begin{array}{l}\text { Minimum teaching } \\
\text { competencies evident to } \\
\text { confirm appointment } \\
\text { at distinguished level }\end{array}$ \\
\hline $\begin{array}{l}\text { Promotion } \\
\text { Practices }\end{array}$ & $\begin{array}{l}\text { On completion of the } \\
\text { contract and graduation } \\
\text { with a PhD emerging } \\
\text { academics may apply for } \\
\text { permanent vacant lecturer } \\
\text { positions }\end{array}$ & $\begin{array}{l}\text { Awarded on the basis of } \\
\text { achievement; clear evidence of } \\
\text { merit; ability to meet the } \\
\text { criteria for promotion, with } \\
\text { supporting evidence at } \\
\text { developing level }\end{array}$ & $\begin{array}{l}\text { As per the previous level. } \\
\text { Awarded on the basis of } \\
\text { achievement; clear evidence } \\
\text { of merit; ability to meet the } \\
\text { criteria with supporting } \\
\text { evidence for promotion at } \\
\text { distinguished level }\end{array}$ \\
\hline $\begin{array}{l}\text { Evaluation of } \\
\text { Teaching and } \\
\text { Courses }\end{array}$ & $\begin{array}{l}\text { Little or no knowledge of } \\
\text { the use of students' } \\
\text { evaluation feedback and } \\
\text { peer review to inform } \\
\text { teaching and curricula } \\
\text { development }\end{array}$ & $\begin{array}{l}\text { Students' evaluation feedback } \\
\text { and other sources (peer } \\
\text { review, literature and self) are } \\
\text { used to reflect on and develop } \\
\text { teaching and curricula at } \\
\text { course level }\end{array}$ & $\begin{array}{l}\text { Extensive use is made of } \\
\text { evaluation feedback from a } \\
\text { variety of sources to inform } \\
\text { scholarship of learning and } \\
\text { teaching, and develop } \\
\text { curricula at programme and } \\
\text { course level }\end{array}$ \\
\hline $\begin{array}{l}\text { Quality } \\
\text { Assurance }\end{array}$ & $\begin{array}{l}\text { Little or no awareness of } \\
\text { policies and initiatives to } \\
\text { enhance institutional / }\end{array}$ & $\begin{array}{l}\text { Supports and implements } \\
\text { policies and initiatives to } \\
\text { enhance institutional learning } \\
\text { and teaching quality standards }\end{array}$ & $\begin{array}{l}\text { Establishes, supports and } \\
\text { leads initiatives and policies } \\
\text { to enhance institutional / } \\
\text { national learning and }\end{array}$ \\
\hline
\end{tabular}




\begin{tabular}{|c|c|c|c|}
\hline \multirow[b]{2}{*}{ Aspects } & \multicolumn{3}{|l|}{ Ladder of Learning } \\
\hline & $\begin{array}{l}\text { Emerging } \\
\text { (Postdoc and Associate } \\
\text { Lecturer) }\end{array}$ & $\begin{array}{l}\text { Developing } \\
\text { (Lecturer and } \\
\text { Senior lecturer) }\end{array}$ & $\begin{array}{l}\text { Distinguished } \\
\text { Associate Professor } \\
\text { and Full Professor }\end{array}$ \\
\hline & $\begin{array}{l}\text { national learning and } \\
\text { teaching quality standards }\end{array}$ & $\begin{array}{l}\text { which have been benchmarked } \\
\text { nationally }\end{array}$ & $\begin{array}{l}\text { teaching quality standards, } \\
\text { benchmarked internationally }\end{array}$ \\
\hline
\end{tabular}

The community element comprises multiple individuals and/or sub-groups who share the same general goal in the Activity System, and influence institutional culture. Academics, administrative personnel and students at higher education institutions may be seen as representing the community in this Activity System. Workshop participants identified senior academics who act as role models as a critical resource to mentor and develop the teaching expertise of less experienced colleagues. Another important support structure for developing teaching expertise and practice is a 'community of practice' formed by academics and other individuals with similar interest in a particular aspect of teaching and/or the scholarship of learning and teaching.

Drawing on the workshop data, institutional practices and literature (Gibbs 2014; AUTCSP 2014; Olsson et al. 2010) the progressive development of the community on the Ladder of Learning is shown in Table 4.

Table 4: Progressive development of community on the Ladder of Learning

\begin{tabular}{|c|c|c|c|}
\hline \multirow[b]{2}{*}{ Aspects } & \multicolumn{3}{|l|}{ Ladder of Learning } \\
\hline & $\begin{array}{l}\text { Emerging } \\
\text { (Postdoc and Associate } \\
\text { Lecturer) }\end{array}$ & $\begin{array}{l}\text { Developing } \\
\text { (Lecturer and } \\
\text { Senior lecturer) }\end{array}$ & $\begin{array}{l}\text { Distinguished } \\
\text { (Associate Professor } \\
\text { and Full Professor) }\end{array}$ \\
\hline Mentoring & $\begin{array}{l}\text { Open to being mentored by } \\
\text { senior colleagues in learning } \\
\text { and teaching scholarship and } \\
\text { practices; engages in peer } \\
\text { review by senior colleagues } \\
\text { to develop teaching and } \\
\text { curricula; co-authorship of } \\
\text { publications and } \\
\text { presentations with senior } \\
\text { colleagues; application for } \\
\text { teaching grants as a team } \\
\text { member; mentored by senior } \\
\text { academics to successfully } \\
\text { supervise postgraduate } \\
\text { students to completion }\end{array}$ & $\begin{array}{l}\text { Transition to mentor and } \\
\text { support junior colleagues in } \\
\text { learning and teaching } \\
\text { scholarship and practices; } \\
\text { accepts and provides peer } \\
\text { review feedback to further } \\
\text { develop teaching and curricula; } \\
\text { co-authorship of publications } \\
\text { and presentations with junior } \\
\text { colleagues; successful } \\
\text { application for teaching grants } \\
\text { and awards as an experienced } \\
\text { team member; } \\
\text { mentor junior colleagues to } \\
\text { successfully supervise } \\
\text { postgraduate students to } \\
\text { completion }\end{array}$ & $\begin{array}{l}\text { Sustained and successful } \\
\text { mentoring of others } \\
\text { (individuals and teams) in } \\
\text { the scholarship of learning } \\
\text { and teaching; provides peer } \\
\text { review feedback to further } \\
\text { develop teaching and } \\
\text { curricula; co-authorship of } \\
\text { publications and } \\
\text { presentations with junior } \\
\text { colleagues; sustained } \\
\text { successful application for } \\
\text { teaching grants, awards or } \\
\text { competitive funding as a } \\
\text { senior team member; } \\
\text { mentor junior colleagues to } \\
\text { successfully supervise } \\
\text { postgraduate students to } \\
\text { completion }\end{array}$ \\
\hline $\begin{array}{l}\text { Communities of } \\
\text { Practice }\end{array}$ & $\begin{array}{l}\text { Invited to participate in } \\
\text { school / faculty scholarly } \\
\text { communities of practice }\end{array}$ & $\begin{array}{l}\text { Leads and enables institutional } \\
\text { / national communities and } \\
\text { scholarly practices }\end{array}$ & $\begin{array}{l}\text { (Inter)national peer } \\
\text { recognition of creation of } \\
\text { and contribution to } \\
\text { communities and scholarly } \\
\text { practices }\end{array}$ \\
\hline
\end{tabular}


The division of labour element in this system refers to both the horizontal division of tasks and the vertical division of power and status which contribute to the structure and culture in a particular institutional context. It is understood that academics will develop their expertise progressively in their careers to address three core functions, namely, teaching, research and academic citizenship. They are expected to divide their time according to various workload models, for example, 40 per cent research, 40 per cent teaching and 20 per cent service (AUTCSP 2014, 8), but promotion policies are traditionally driven by research productivity, particularly at research-intensive institutions, despite rhetoric to the contrary. Consequently, academics may be reluctant to devote too much time to teaching. High teaching loads are addressed in some institutions by employing assistant lecturers and/or postdoctoral students who are represented on the Ladder of Learning as emerging or early career academics.

The progressive development of the division of labour on the Ladder of Learning is shown in Table 5, based on the workshop data, institutional practices and literature (Gibbs 2014; AUTCSP 2014; Olsson et al. 2010).

Table 5: Progressive development of division of labour on the Ladder of Learning

\begin{tabular}{|c|c|c|c|}
\hline \multirow[b]{2}{*}{ Aspects } & \multicolumn{3}{|l|}{ Ladder of Learning } \\
\hline & $\begin{array}{l}\text { Emerging } \\
\text { (Postdoc and Associate } \\
\text { Lecturer) }\end{array}$ & $\begin{array}{l}\text { Developing } \\
\text { (Lecturer and } \\
\text { Senior lecturer) }\end{array}$ & $\begin{array}{l}\text { Distinguished } \\
\text { (Associate Professor } \\
\text { and Full Professor) }\end{array}$ \\
\hline Status & $\begin{array}{l}\text { Is aware of the need to } \\
\text { consciously develop } \\
\text { professional and personal } \\
\text { effectiveness }\end{array}$ & $\begin{array}{l}\text { Demonstrates progress } \\
\text { towards professional and } \\
\text { personal effectiveness }\end{array}$ & $\begin{array}{l}\text { Demonstrates professional and } \\
\text { personal effectiveness }\end{array}$ \\
\hline $\begin{array}{l}\text { Teaching } \\
\text { workload }\end{array}$ & $\begin{array}{l}\text { Focus on Department/School } \\
\text { impact: UG and PG teaching } \\
\text { workload that is negotiated } \\
\text { with greater emphasis on } \\
\text { UG, and developing } \\
\text { expertise to supervise PG } \\
\text { students }\end{array}$ & $\begin{array}{l}\text { Focus on Institutional } \\
\text { impact: UG and PG } \\
\text { teaching workload that is } \\
\text { negotiated; sound } \\
\text { expertise to supervise PG } \\
\text { students }\end{array}$ & $\begin{array}{l}\text { Focus on National / } \\
\text { International Impact: UG and } \\
\text { PG teaching workload that is } \\
\text { negotiated with emphasis on } \\
\text { PG and mentoring of } \\
\text { colleagues to supervise PG } \\
\text { students }\end{array}$ \\
\hline $\begin{array}{l}\text { Professional } \\
\text { Development }\end{array}$ & $\begin{array}{l}\text { May engage in professional } \\
\text { development activities } \\
\text { related to learning and } \\
\text { teaching }\end{array}$ & $\begin{array}{l}\text { Systematic participation in } \\
\text { professional development } \\
\text { activities related to learning } \\
\text { and teaching; successful } \\
\text { completion of a tertiary } \\
\text { teaching qualification; } \\
\text { enables and supports the } \\
\text { provision of professional } \\
\text { development of junior } \\
\text { colleagues; }\end{array}$ & $\begin{array}{l}\text { Proactive and sustained } \\
\text { leadership to support the } \\
\text { professional development of } \\
\text { others; contributes to and/or } \\
\text { leads/creates professional } \\
\text { development } \\
\text { courses/opportunities }\end{array}$ \\
\hline
\end{tabular}

\section{CONCLUSION}

Activity Theory provided a useful conceptual framework for identifying and developing the aspects involved in the professional development of academics. These aspects were then 
aligned on the Ladder of Learning'. Firstly, during the data analysis phase, Activity Theory offered the conceptual tools to determine the key aspects which were to be included on the Ladder. Secondly, Activity Theory provided the scope to construct interpretations of the kinds of developmental opportunities that academics may need for career progression in higher education. Thirdly, Activity Theory allowed for the interpretation of how academics' professional development in teaching takes place in different contexts.

The findings of this investigation point to complexities concerning the teaching competence of academics. To begin with, the diversity of academic staff expertise at different career levels may mean that senior academics display teaching competencies associated with novice practice, while some emerging academics may display proficiencies normally associated with distinguished practice, thus making the explicit progressive development of needs and practices on the Ladder challenging. In addition, the lack of common understanding of what 'quality' teaching means and what counts as 'evidence' may result in resistance to attempts to support and develop teaching expertise or to provide a level of certainty to the evaluation of teaching for career progression. In fact, the varied expertise of academic developers themselves may contribute to this resistance and uncertainty. Lastly, different structures within and across an institution may either enable or constrain a generic approach to academics' professional development. In general, the collegial sharing of experiences among workshop participants raised common issues, as discussed in this article.

The Ladder of Learning, which draws on these common issues, serves to articulate and concretise progressive developmental opportunities for maturity in practice related to teaching. The conceptualisation of these opportunities also serves to align interventions to guide the development of portfolios, allow the application of theory and practice through the scholarship of learning and teaching, and informs the peer review of teaching for institutional probation and promotion purposes. The Ladder of Learning may also serve as a diagnostic framework, not only for academics and/or academic development practitioners seeking to understand where they need to direct efforts to grow teaching competence, but also at the institutional level where the 'cycle of expansive learning' (Engeström 2000) may assist in redefining institutional goals/outcomes to meet current needs. Finally, the Ladder of Learning may serve nationally to benchmark teaching quality within and across higher education institutions in South Africa.

In the next phase of the investigation, feedback from stakeholders at higher education institutions nationally will afford the authors an opportunity to refine the progressive development of needs and practices on the Ladder of Learning. Through the process of gathering further input and feedback, the complexity and generic nature of the aspects on the 
Ladder of Learning will be further contextualised to meet the needs of different higher education institutions in South Africa.

\section{NOTE}

1 The Professional Development Special Interest Group was held in August 2014 at the University of the Witwatersrand. The workshop was titled: 'Conceptualising Strategic Alignment of Academic Staff Development and academic development practitioner’s knowledge and practices’.

\section{REFERENCES}

Archer, M. 1995. Realist social theory: The morphogenetic approach. Cambridge: Cambridge University Press.

Archer, M. 1996. Culture and agency: The place of culture in social theory. Cambridge: Cambridge University Press.

Archer, M. 1998. Social theory and the analysis of society. In Knowing the social world, ed. T. May and M. Williams, 69-85. Buckingham: Open University Press.

Australian University Teaching Criteria and Standards Project. 2014. http://uniteachingcriteria.edu.au/ wp-content/uploads/2013/12/Framework_indicative-standards-arrange-by-criteria.pdf (accessed 13 April 2015).

AUTCSP see Australian University Teaching Criteria and Standards Project.

CHE see Council on Higher Education.

Council on Higher Education. 2013. A proposal for undergraduate curriculum reform in South Africa: The case for a flexible curriculum structure. Report of the Task Team on Undergraduate Curriculum Structure. Discussion Document. Council on Higher Education. Pretoria. South Africa.

Engeström, Y. 1987. Learning by expanding: An activity-theoretical approach to developmental research. Helsinki: Orienta-Konsultit.

Engeström, Y. 1993. Developmental studies of work as a testbench of activity theory: The case of primary care medical practice. In Understanding practice: Perspectives on activity and context, ed. S. Chaiklin and J. Lave, 64-103. Cambridge: Cambridge University Press.

Engeström, Y. 2000. From individual action to collective activity and back: Developmental work research as an interventionist methodology. In Workplace studies, ed. P. Luff, J. Hindmarsh and C. Heath, 303-315. Cambridge: Cambridge University Press

Gibbs, G. 2014. At the heart of the higher education debate. Times Higher Education, $9^{\text {th }}$ October. http://www.timeshighereducation.co.uk/news/graham-gibbs-on-teaching-lecturers-toteach/2016202.article (accessed 31 March 2015).

Gosling, D. 2009. Academic development identity and positionality. SRHE Academic Development Network, October $30^{\text {th }}$ 2009. http://www.davidgosling.net/userfiles/srhe\%20academic\%20 development\%20networkoctober\%2030th\%202009.pdf (accessed 19 February 2015).

Linder, K. E. and P. Felten, 2015. Understanding the work of academic development. International Journal for Academic Development 20(1): 1-3. DOI:10.1080/1360144X.2014.998875.

Olsson, T., K. Mårtensson and T. Roxå. 2010. Pedagogical competence - a development perspective from Lund University. In A Swedish perspective on pedagogical competence, ed. A. Ryegård, K. Apelgren and T. Olsson, 121-132. Uppsala University. 